Al-Bayyinah: Journal of Islamic Law-ISSN: 1979-7486 (p); 2580-5088 (e) Volume VI Number 1, pp. 43-58

\title{
MEMAHAMI KONSEP MAQASHID AL-SYARI'AH DALAM FILSAFAT HUKUM ISLAM
}

\section{Hj. St. Najmah}

(Dosen Tetap STAIN Watampone, Sulawesi Selatan, Indonesia, email:sitti.najmah@yahoo.co.id

\section{Abstract}

Maqashid al-syari'ah is target and meaning desired by syara' in specifying or it all or most his lawses, or target oves and specified secret God in each God law. This, Maqashid al-syari'ah is existing secret and target and desired God in specifying, ad for as a whole and some of laws of God. Target of syari'ah, at the core of is to look after kindliness of human being and obviate badness, either in world and in eternity/the beyond.

Theory of maqashid al syari'ah becoming fulcrums the core important is kindliness of human being in eternity/the beyond and world. This matter, new earn isn't it if five fundamental element can be realized and looked after. Ad for fundamental element, is to look after religion, soul, mind, clan and look after estae.

\section{Kata Kunci: Maqashid dan al-syari'ah}

\section{PENDAHULUAN}

\section{A. Latar Belakang}

Hukum Islam diyakini oleh umat Islam sebagai hukum yang bersumber pada wahyu Tuhan (Devine low). Keyakinan itu didasarkan pada kenyataan bahwa sumber hukum dalam Islam adalah al-Quran dan Sunnah. Allah dan Rasul-Nya lazim disebut al-syar'I (law giver). Namun demikian, diketahui bersama bahwa jumlah ayat-ayat Alquran dan Sunnah Rasulullah terbatas, sementara problem hukum terus bertambah seiring dengan perkembangan yang terjadi dalam kehidupan umat 
manusia. Untuk itulah, upaya untuk menggali dan menemukan jawaban hukum (istimbath al-hukm ) harus terus dilakukan oleh para ahli hukum Islam.

Dalam ilmu usul fikih, upaya untuk menimbah pesanpesan yang terkandung dalam Alquran dan Sunnah Rasulullah dapat dilakukan melalui tiga pendekatan, yaitu pendekatan kebahasaan, pendekatan maqashid al-syari'ah dan pendekatan lewat penyelesaian beberapa dalil yang bertentangan.

Pendekatan yang disebut pertama merupakan suatu upaya untuk memahami hukum melalui bunyi bahasa yang ada di dalam Alquran dan Sunnah Rasulullah. Namun, sebagaimana disinggung di muka, pendekatan itu memiliki kelemahan yakni bahwa ayat-ayat dan hadis-hadis hukum secara kuantitatif sangat terbatas jumlahnya sehingga tidak mampu memberikan jawaban atas persoalan yang belum disebut secara explicit dalam nash.

Maqashid al-syari'ah, seperti ditegaskan oleh Abdul Wahab Khallaf adalah hal yang sangat penting yang dapat dijadikan alat bantu untuk memahami redaksi Alquran dan Sunnah, menyelesaikan dalil-dalil yang bertentangan dan yang sangat penting lagi adalah untuk menetapkan hukum terhadap kasus yang tidak tertampung oleh teks Alquran dan Sunnah. ${ }^{1}$

Alquran dan sunnah merupakan dua sumber utama hukum Islam, keduanya terdapat ajaran-ajaran mengenai segala aspek kehidupan manusia. Namun, keduanya umumnya hanya dalam arti prinsip-prinsip dasarnya. Sedangkan untuk menjawab persoalan-persoalan yang terperinci diperlukan ijtihad.

Ijtihad sebagai upaya maksimal untuk menemukan hukum suatu persoalan harus dilaksanakan dengan memperhatikan tujuan-tujuan atau maqashid al-syari'ah. Seorang mujtahid harus memperhatikan tujuan ditetapkannya sebuah ketentuan hukum dan meneliti persoalan yang sedang dihadapi untuk memastikan bahwa dengan diterapkannya hukum tersebut bagi persoalan bersangkutan akan mengantarkan tercapainya maqashid al-syari'ah dan bukan sebaliknya. Pengetahuan akan maqashid al-syari'ah juga diperlukan untuk mengetahui apakah bagi suatu kasus masih dapat diterapkan 1983), h. 23.

${ }^{1}$ Abd. Wahab Khallaf, 'Ilmu Ushul Figh, (Kuwait: Dar al-Qalam, 
suatu ketentuan hukum tertentu mengingat telah adanya perubahan sosial. Ataukah tidak. ${ }^{2}$ Dengan demikian, pengetahuan tentang maqashid al-syari'ah merupakan hal yang teramat penting dalam melakukan ijtihad.

Dan urgensi maqashid al-syari'ah dalam berijtihad sudah didasari para fuqaha sejak masa yang sangat dini dalam sejarah Islam, meskipun mereka tidak menyebut istilah maqashid al-syari'ah. Penggunan istilah dan perumusan konsep maqashid al-syari'ah pertama kali dilakukan oleh Syatibi. ${ }^{3}$

Kajian tentang maqashid al-syari'ah merupakan kajian yang menarik dalam usul fikih. Dalam perkembangan berikutnya, kajian itu juga merupakan kajian utama dalam Filsafat Huum Islam, sehingga dapat dikatakan bahwa istilah maqashid al-syari'ah identik dengan istilah Filsafat Hukum Islam.

\section{B. Rumusan Masalah}

Berdasarkan dari uraian tersebut di atas, maka maqashid al-syari'ah dipandang sebagaia aspek filsafat hukum Islam yang sangat penting dalam rangka dinamika dan perkembangan hukum Islam. Oleh karena itu, permasalahan pokok yang akan dibahas dalam tulisan ini adalah bagaimana memahami teori maqashid al-syari'ah dan macam-macam maqashid al-syari'ah?

\section{Karangka Teori}

Secara etimologi maqashid al-syari'ah terdiri dari dua kata maqashid dan al-syari'ah. Maqashid adalah bentuk jamak dari kata maqshad yang berarti niat, kehendak, maksud dan tujuan. ${ }^{4}$ Sedangkan Syari'ah berarti jalan menuju sumber air. ${ }^{5}$ Secara terminologi syari'ah adalah segala ketentuan allah yang disyariatkan kepada hamba-Nya yang mencakup akidah, akhlak,

h. 124 .

${ }^{2}$ Fathurraman Djamil, Filsafat Hukum Islam, (Jakarta: Logos, 1998),

3 Asafri Jaya Bakri, Konsep maqashid syari'ah Menurut al-syatibi, (Jakarta: Rajawali Press. 1999), h. 57

4 Hans Wehr, A Dictionary of Modern Written Arabic, (London: George Allen and Unwin Ltd, 1997), h. 767.

${ }^{5}$ Ibn Manzur, Lisan al-Arab, (Beirut: Dar Al-Fikr, t.th) jilid VII, h. 175 
ibadah dan muamalah. ${ }^{6}$ Akan tetapi dalam perkembangannya, syari'ah mengalami penyempitan makna, yaitu hanya terbatas pada hukum yang mengatur hubungan manusia dengan Tuhannya, dan hubungan manusia dengan manusia.

Dengan demikian, maqashid al-syari'ah dapat didefinisikan sebagai "makna dan tujuan yang dikehendaki oleh syara' dalam menetapkan atau mensyari'atkan semua atau sebagian besar hukum-hukumnya, atau tujuan-tujuan dan rahasia-rahasia yang ditetapkan Allah pada setiap hukum-Nya". Jadi, maqashid al-syari'ah merupakan tujuan-tujuan dan rahasia-rahasia yang ada dikehendaki Allah dalam menetapkan, semua atau sebagian hukum-hukum-Nya. Tujuan syari'ah, pada intinya adalah untuk memelihara kemaslahatan manusia dan menghindarkan mafsadah, baik di dunia maupun di akhirat. ${ }^{7}$ Berkaitan dengan itulah, maka perumusan teori maqashid alsyari'ah oleh al-Syatibi dipandang sebagai upaya menetapkan maslaha sebagai unsur penting tujuan-tujuan hukum Islam.

Perumusan maqashid al-syari'ah secara umum bertitik tolak dari kandungan ayat-ayat Alquran yang menunjukan bahwa hukum-hukum Tuhan mengandung kemaslahatan. Ayatayat tersebut antara lain :

Dalam surat al-Anbiya: 107

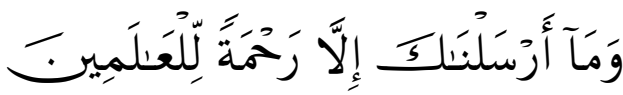

Terjemahannya: Dan tidaklah kami mengutus kamu melainkan untuk menjadi rahmat bagi semesta alam (alanbiya: 107).

6 Manna'al-Qaththan, al-Tasyri' wa al-Fiqh fi al-Islam, (Beirut: Muassasah al-Risalah, t.th), h. 14.

7 Al-Syatibi, Al-Muwafaqath fi Ushul al-Ahkam, Juz II, (Kairo: Muhammad Ali Sabih, t.th.), h. 3.

${ }^{8}$ Muhammad Khalid Mas'ud, Islamic Legal Philosophy (Islamabad: Islamic Researsh Institute, 1997), h. 223. 
Dalam Surat al-Nisa: 165

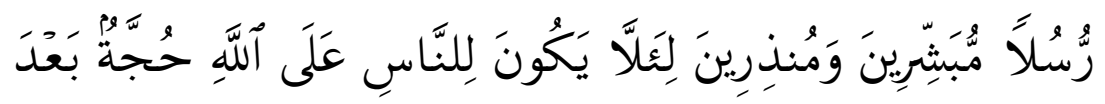

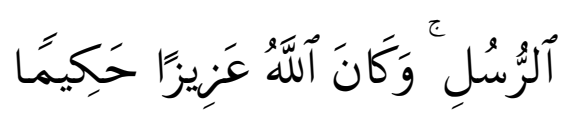

Terjemahannya: (mereka kami utus) selaku Rasul-rasul pembawa berita gembira dan pemberi peringatan agar supaya tidak ada alasan bagi manusia membantah Allah sesudah diutusnya Rasul-rasul itu. Dan adalah Allah Maha Perkasa lagi Maha Bijaksana.

Dalam surat al-Zariyat: 56

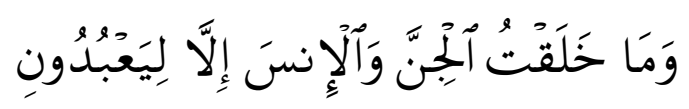

Terjemahannya: Dan aku tidak menciptakan Jin dan manusia melainkan supaya ereka mengabdi kepada-Ku.

Dalam sura al-Mulk: 2

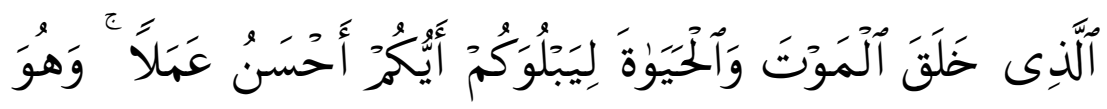

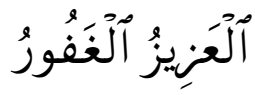

Terjemahnnya: yang menjadikan mati dan hidup, supaya Dia menguji kamu, siapa diantara kamu yang lebih baik amalnya. Dan Dia Maha Perkasa lagi Maha Pengampun.

Dalam surat al-Ankabut: 45

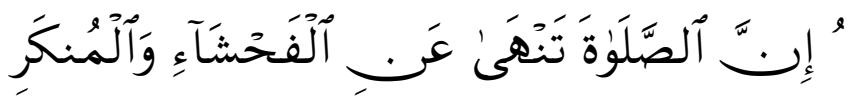

Terjemahannya: Sesungguhnya shalat itu mencegah dari (perbuatan-perbuatan) keji dan mungkar. 
Itukah sebagian dari Ayat-ayat yang menunjukan adanya maqashid al-syari'ah di samping ayat-ayat lain yang tidak mungkin dicantumkan seluruhnya disini. Berdasarkan ayat-ayat tersebut, al-Syatibi mengatakan bahwa maqashid al-syari'ah dalam arti kemaslahatan terdapat dalam semua aspek hukum.

\section{Metode Penelitian}

Penelitian ini termasuk jenis penelitian deskriptif, adapun data yang dikaji termasuk jenis data kualitatif. Data yang dimaksud dihimpun melalui telaah pustak (library research) yang terdiri atas berbagai referensi yng berkaitan dengan pembahasan dalam penelitian ini. Sedangkan analisis data dilakukan dengan menggunakan teknik deduktif dan induktif.

\section{PEMBAHASAN}

\section{A. Teori Maqashid al-Syari'ah}

Apabila ditelusuri perkembangan pemikiran hukum Islam, tampaknya termasuk maqashid al-syari'ah baru dikenal setelah al-Syatibi menggagas konsep tersebut. Sebelumnya pembicaraan "maqashid al-syari'ah" hanya dapat ditemui dari pemikiran ulama tentang illat hukum dan maslahat. Dalam maqashid al-syari'ah berarti "maksud atau tujuan disyari'atkan hukum Islam", sendiri yang menjadi bahasan utamanya adalah masalah hikmat dan illat ditetapkannya suatu hukum.

Abu Ishak al-Syatibi melaporkan hasil penelitian para ulama terhadap ayat-ayat Alquran dan Sunnah Rasulullah yang mengungkapkan bahwa disyari'atkannya hukum Allah adalah untuk mewujudkan kemaslahatan umat manusia, baik di dunia maupun di akhirat. ${ }^{9}$ Beliau sendiri sepakat untuk mengatakan bahwa semua kewajiban (taklif) diciptakan dalam rangka merealisasikan kemaslahatan hamba. Menurutnya, tidak satu pun hukum Allah yang tidak mempunyai tujuan. Hukum yang tidak mempunyai tujuan sama dengan taklif (membebankan sesuatu yang tidak dapat dilaksanakan). Satu hal yang tidak mungkin terjadi pada hukum tuhan. ${ }^{10}$

${ }^{9}$ Al-Syatibi, Al-Muwafaqat fi Ushul al-Syari'ah, Jilid II (Kairo: Mustafa Muhammad, t.th.), h. 6.

${ }^{10}$ Ibid., h. 150. 
Maqashid al-Syari'ah dalam persfektif maqashid alsyar'i mengandung empat aspek pokok bahasan, yaitu:

1. Tujuan awal syari'at adalah kemaslahatan manusia di dunia dan akhirat.

2. Syari'at sebagai sesuatu yang harus dipahami

3. Syari'at sebagai sesuatu hukum taklif yang harus dilakukan

4. Tujuan Syari'at adalah membawa manusia ke bawah naungan hukum. ${ }^{11}$

Aspek yang disebut pertama berkaitan dengan isi dn hakekat maqashid al-syari'ah. Aspek kedua berkaitan dengan dimensi bahasa agar syari'at dapat dipahami sehingga dicapai kemaslahatan yang dikandungnya. Aspek ketiga berkaitan dengan pelaksanaan ketentuan-ketentuan syari'at dalam rangka mewujudkan kemaslahatan. Aspek terakhir berhubungan dengan kepatuhan manusia sebagai mukallaf di bawah dan terhadap hukum-hukum Allah. Dengan bahasa lain, aspek terakhir ini berusaha membebaskan manusia dari kekangan hawa nafsu.

Aspek pertama sebagai inti, dapat terwujud dengan pelaksanaan taklif atau pembebanan hukum terhadap hamba, sebagaimana terdapat pada aspek ketiga. Taklif sendiri tidak dapat dilakukan kecuali memiliki pemahaman baik lafal ataupun maknawi, sebagaimana pada aspek kedua. Selanjutnya, pemahaman dan pelaksanaan taklif dapat membawa manusia berada di bawah lindungan hukum, lepas dari kungkungan hawa nafsu, sebagaimana aspek keempat. Demikianlah tujuan diciptakannya syari'at Islam. Yakni kemaslahatan manusia di dunia dan akhirat, sebagaimana terdapat dalam aspek pertama. ${ }^{12}$

Selanjutnya, kemaslahatan dunia dan akhirat, yang menjadi tujuan utama syari'at baru dapat direalisasikan apabila lima unsur pokok bias diwujudkan dan dipelihara. Kelima unsur pokok (al-kuliyyat al-khams) tersebut, menurut al-Syatibi dan juga para Usuliyyin, adalah agama, jiwa, akal, keturunan dan harta. Seorang mukallaf akan memperoleh kemaslahatan, jika ia dapat memperoleh lima hal pokok tersebut, sebaliknya ia akan

${ }^{11}$ Ibid., h. 5. Dalam tulisan ini maqashid al-mukallaf tidak dibahas lebih lanjut, karena lebih menggambarkan sikap mukallaf terhadap maqashid al-syari'ah.

${ }^{12}$ Ibid. 
merasakan mafsadat, manakala lima unsur itu tidak dipelihara secara baik.

Kelima unsur pokok tersebut, menurut al-Syatibi, digali dan didasarkan atas dalil-dalil Alquran dan hadis. Setiap ayat dan hadis hukum bila diteliti akan ditemukan alasan pembentukannya yang tidak lain adalah untuk memelihara lima unsur tersebut. Berdasarkan penelitiannya, ia berkesimpulan bahwa dalil-dalil yang digunakan dala menetapkan al-Kuliyyat al-Kahms termasuk dalil qath'i, maka ia juga dapat dikategorikan qath 'i. istilah qath'I di sini, agaknya menurut alSyatibi, adalah bahwa al-Kuliyyat al-Kahms, dari segi landasan hukum, dapat dipertanggungjawabkan dan oleh karenanya ia dapat dijadikan sebagai dasar menetapkan hukum. ${ }^{13}$

Lima unsur diatas, selanjutnya dibedakan kedalam tiga peringkat kebutuhan, berturut-turut dar-riyyat, hajiyyat dan tahsiniyyat. Sesungguhnya, pengelompokan itu dimaksudkan untuk memelihara dan mewujudkan kelima unsur pokok. Adanya pembagian tingkatan itu lebih didasarkan pada skala prioritas dan tingkat urgenitasnya. Perbedaan tingkat kebutuhan itu akan terlihat, manakala kemaslahatan pada masing-masing tingkat saling bertentangan.

Kebutuhan dar-riyyat adalah kebutuhan-kebutuhan esensial, kebutuhan primer yang harus ada. Apabila hal itu tidak terpenuhi, maka kehidupan manusia akan terancam baik di dunia maupun diakhirat. Hajiyyat adalah kebutuhan sekunder yang jika terpenuhi akan dapat menghindarkan manusia dari kesulitan hidupnya, sebaliknya jika tidak terwujud ia tidak akan mengancam kelima pokok diatas. Sedangkan kelompok terakhir (tahsiniyyat) adalah kebutuhan pelengkap yaitu, sebagaimana ditegaskan oleh al-Syatibi, hal-hal yang merupakan kepatuhan menurut adat istiadat menghindarkan hal-hal yang tidak sedap dipandang mata dan berhias dengan keindahan yang sesuai dengan tuntunan norma dan akhlak.

Maqashid al-Syari'ah, sebagai telah disebut dimuka, adalah suatu pendekatan hukum yang sangat penting, lebih elastis dan fleksibel serta mampu menyelesaikan berbagai persoalan yang tidak terjawab lewat pendekatan kebahasaan.

\footnotetext{
${ }^{13}$ Fathurrahman Djamil, op. cit., h. 126.
} 
Metode-metode istimbat hukum, seperti qiyas, istihsan, maslahah al-mursalah dan sebagainya merupakan metode pengembangan hukum Islam yang didasarkan atas maqashid alsyari'ah. Misalnya, qiyas baru bias dilaksanakan bilamana dapat ditemukan maqashid al-syari'ah-nya yang merupakan alasan logis (illat) dari suatu hukum. ${ }^{14}$

Dalam hal ini, cara mengetahui atau memahami maqashid al-syari'ah. Dalam masalah ini, para ulama menurut al-Syatibi terbagi kepada tiga kelompok dengan metode pemahaman yang berbeda-beda, yakni: pertama, ulama yang berpendapat bahwa maqashid al-syari'ah adalah sesuatu yang abstrak, tidak dapat diketahui kecuali lewat petunjuk Tuhan yang terungkap dalam bentuk zahir lafal yang jelas. Petunjuk itu tidak memerlukan penelitian, yang pada gilirannya akan bertentangan dengan kehendak bunyi lafal. Kelompok itu disebut al-Zahiriyah.

Kedua, ulama yang tidak menempuh pendekatan zahir lafal nash. Kelompok itu terbagi menjadi dua golongan. Golongan pertama berpendapat bahwa maqashid al-syari'ah diketahui bukan dari zahir lafal dan bukan pula dari tunjukan zahir lafal. Maqashid al-Syari'ah merupkan hal lain yang ada dibalik tunjukan zahir lafaz yang terdapat dalam semua aspek syari'at. Kelompok itu disebut ulama al-Batiniyyah. Golongan kedua berpendapat bahwa maqashid al-syari'ah harus dikaitkan dengan pengertian lafal. Artinya zahir lafal tidak harus mengandung tunjukan mutlak. Apabila terdapat pertentangan zahir lafal dengan nalar, maka yang diutamakan dan didahulukan adalah pengertian nalar, baik atas dasar keharusan menjaga kemaslahatan atau tidak. Kelompok itu disebut ulama al-Muta'ammiqin fi al-Qiyas.

Ketiga, ulama yang melakukan penggabungan dua pendekatan (zahir lafal dan pertimbangan makna illat) dalam suatu bentu yang tidak merusak pengertian zahir lafal dan tidak pula merusak kandungan makna/illat, sehingga tetap berjalan secara harmoni tanpa kontradiksi-kontradiksi. Kelompok itu disebut ulama a-Rasikhin. ${ }^{15}$

${ }^{14}$ Satria Efendi, op. cit., h. 97.

${ }^{15}$ Al-Syatibi, jilid II, op. cit., h. 393. 
Al-Syatibi termasuk dalam kelompok ketiga (ulama alRasikhin). Hal itu dapat dilihat dari tiga cara yang dirumuskannya untuk memahami maqashid al-syari'ah, yaitu:

1. Melakukan analis terhadap lafal perintah dan larangan. Suatu perintah menurutnya menghendaki perwujudan dari sesuatu yang diperintahkan. Perwujudan isi dari perintah itu menjadi tujuan yang dikehendaki oleh alSyar'i. Demikian pula sebaliknya. Sebuah larangan menghendaki suatu perbuatan yang dilarang itu ditinggalkan. Keharusan meninggalkan perbuatan yang dilarang merupakan tujuan yang diinginkan oleh Tuhan.

2. Menelaah illat al-amr (perintah) dan al-nahiy (larangan). Menurutnya pemahaman maqashid al-syari'ah dapat dilakukan melalui analisis illat hukum yang terdapat dalam Alquran dan Hadis. Illat hukum itu adakalanya tertulis secara jelas dalam ayat atau hadis, maka menurutnya, harus diikuti apa yang tertulis itu. Namun, apabila illat tidak tertulis, maka harus dilakukan tawaqquf. Tawaqquf disini bukan bersifat pasti tapi sebaliknya. Al-Syatibi mengemukakan bahwa tawaqquf dalam masalah mu'amalah misalnya, dapat dilakukan ta'addi, jika tujuan hukum itu dapat diketahui dengan ta'addi tersebut. Selain itu kedinamisan al-Syatibi juga dapat dilihat definisinya mengenai illat. Menurutnya, illat adalah kemaslahatan-kemaslahatan an hikmahhikmah yang berkaitan dengan perintah (al-amr) dan kebolehan (al-ibadah) dan kemafsadatan (al-mafasid) yang berkaitan denga larangan (an-nahiy). Dengan demikian, illat suatu hukum adalah kemaslahatan dan kemafsadatan itu sendiri. ${ }^{17}$

3. Analisis terhadap sikap diam syar'i. ini merupakan cara memahami persoalan-persoalan hukum yang tidak disebut oleh al-Syar'i.

Dari cara-cara yang dijelaskan oleh al-Syatibi dalam mengetahui maqashid al-syari'ah di atas, maka dapat diketahui bahwa untuk memahami hal itu diperlukan beberapa syarat

${ }^{16}$ Ibid. h. 393.

${ }^{17}$ Ibid. h. 394. 
pokok yang harus dipenuhi oleh seorang mujtahid. Syarat-syarat tersebut menurut al-Syatibi adalah:

1. Memiliki pengetahuan bahasa arab

2. Memiliki pengetahuan tentang sunnah

3. Mengetahui sebab turunnya ayat.

\section{B. Pembagian Maqashid al-Syari'ah}

Dalam karya monumentalnya, al-muwafaqat., al-Syatibi membagi maqashid menjadi dua macam. Pertama adalah dari sisi tujuan syar'I, dan kedua adalah dari sisi tujuan mukallaf. Hal ini dapat dilihat:

1. Tujuan syar'i dalam menetapkan syari'at sejak awal

2. Tujuan syar'i dalam menetapkan syari'at dari sisi untuk dipahami

3. Tujuan syar'i dalam menetapkan syari'at dari sisi untuk taklif dan

4. Tujuan syar'i dalam menetapkan syari'at dari sisi untuk membawa manusia mukallaf kebawah naungan hukumNya. ${ }^{18}$

Aspek pertama berkaitan dengan hakekat. Aspek kedua berkaitan dengan dimensi bahasa agar dapat dipahami. Aspek ketiga berkaitan dengan pelaksanaan ketentuan-ketentuan syari'at dan kemampuan manusia untuk melaksanakannya. Dan aspek keempat berkaitan dengan kepatuhan manusia mukallaf untuk masuk kedalam pengaturan syari'at sehingga terbebas dari kekangan hawa nafsunya.

Aspek kedua, ketiga dan keempat pada dasarnya lebih merupakan penunjang bagi aspek pertama. Aspek pertama sebagai intinya hanya dapat terwujud melalui aspek keempat yaitu, kepatuhan manusia untuk masuk kedalam pengaturan syari'at dan membebaskan diri dari kekangan hawa nafsunya. Kepatuhan itu baru dapat terlaksana setelah adanya taklif yang merupakan aspek ketiga, dan adanya taklif serta kepatuhan manusia tidak akan terwujud kecuali jika mereka memiliki pemahaman terhadap syari'at sebagai aspek kedua.

Dengan memperhatikan sistematisasi yang dibuat alSyatibi maka nampaknya yang dimaksud dengan maqashid al-

${ }^{18}$ Al-Syatibi, al-Muwafaqat, Juz 2, op. cit. h. 3. 
syari'ah adalah aspek pertama diatas. ${ }^{19}$ Dalam paparannya teradap aspek pertama itu al-Syatibi membagi maqashid alsyari'ah kedalam tiga tingkat, yaitu daruriyat, hajjiyat dan tahsiniyat. Ketiga tingkat ini masing-masing dan secara bersamaan adalah memelihara agama, jiwa, keturunan, harta dan akal.

Tingkat daruriyat adalah hal-hal yang bersifat esensial bagi kehidupan manusia baik di dunia maupun di akhirat dan karenanya arus dipelihara. Hal-hal yang esensial tersebut adalah agama, jiwa, akal, keturunan dan harta. Pemeliharaan hal tersebut adalah dalam arti jangan sampai eksistensinya terancam. Tidak terwujudnya kemaslahatan manusia. Di dunia ini mereka akan mengalami kerusakan, kekacauan bahka kehancuran dan di akhirat nanti mereka tidak akan selamat bahkan akan mengalami kerugian yang fatal.

Untuk memelihara agama, diwajibkan antara lain, melaksanakan shalat, zakat, puasa dan haji. Untuk memelihara jiwa diharuskan dipenuhinya kebutuhan pokok berupa makanan, pakaian, dan tempat tinggal. Untuk memelihara keturunan disyariatkan nikah dan diharamkan zina. Dan untuk memelihara harta, ditetapkan tata cara pemilikan harta dan laranga mengambil harta orang lain dengan cara orang lain dengan cara yang tidak syah.

Berbeda dengan daruriyat, hajjiyat bukanlah hal-hal yang esensial, melainkan hal-hal yang perlu diperhatikan untuk menghindarkan manusia dari kesulitan dalam hidupnya. Tidak terpeliharanya kelompok itu tidak akan menimbulkan kerusakan yang dapat menghilangkan kemaslahatan umum, melainkan hanya kesulitan dan kesempitan bagi mukallaf.

Pada tingkatan itu Allah swt. mensyariatkan, antara lain jama' dan qasar shalat bagi orang yang sedang bepergian, dalam rangka memelihara agama; diperbolehkannya berburu binatang untuk menikmati makanan yang lezat, dalam rangka memelihara jiwa; dianjurkan menuntut ilmu pengetahuan sebagai pengembang dalam rangka memelihara akal; ketentuan menyebut mahar oleh suami pada waktu akad nikah, dalam

${ }^{19}$ Ibid. h. 4. 
rangka memelihara keturunan; dan diizinkannya transaksi salam untuk memelihara harta.

Sedangkan tahsiniyat adalah hal-hal yang berkaitan denga etika yaitu melakukan hal-hal yang pantas dan menjauhi hal-hal yang tidak pantas. Termasuk dalam kelompok itu adalah melaksanakan ibadah sunnah makan dan minum dengan cara yang baik, menghindarkan diri dari mendengarkan sesuatu yang tidak bermanfaat.

Bila diperhatikan dalam usaha memelihara unsur pokok di atas, ketiga kelompok maqashid di atas dapat dipisahkan. Hanya saja tingkat kepentingan berbeda satu sama lain. Kelompok daruriyat dapat dikatakan sebagai kebutuhan primer yang kalau diabaikan maka akan berakibat terancamnya eksistensi kelima pokok itu. Kelompok hajiyat dapat dikatakan sebagai kebutuhan sekunder, dalam arti kalau diabaikan tidak akan mengancam eksistensinya, melainkan akan mempersulit dan mempersempit kehidupan manusia. Sedangkan kelompok tahsiniyat dapat dikatakan sebagai komplemen atau pelengkap yang kalau diabaikan tidak akan menimbulkan kesulitan apalagi mengancam eksistensi kelima pokok tersebut, tetapi akan mengakibatkan ketidakpantasan. ${ }^{20}$ Dengan kata lain daruriyat merupakan pokok, hajiyat merupakan penyempurna bagi daruriyat dan tahsiniyat merupakan penyempurna bagi hajiyat ${ }^{21}$.

Dalam setiap tingkat seperti dijelaskan di atas, terdapat hal-hal yang menjadi penyempurnaan atau pelengkap dalam tingkat daruriyat misalnya, diperintahkannya berjama'ah dalam shalat, untuk memelihara agama dan ditentukan adanya perimbangan dalam melaksnakan qisas, untuk memelihara jiwa. Dalam tingkat hajiyat misalnya, adanya saksi dalam jual beli, untuk memelihara harta; dan perlunya mempertimbangkan kafa'ah dalam pernikahan, untuk memelihara keturunan. Dan dalam tingkat tahsiniyat seperti melaksanakan sunnah-sunnah thaharah untuk memelihara agama. ${ }^{22}$

Adanya stratifikasi di atas bukan berarti bahwa kelompok kedua atau ketiga dapat dianggap tidak penting dan karenanya dapat diabaikan begitu saja. Stratifikasi tersebut lebih

\footnotetext{
${ }^{20}$ Fathurrahman Djamil, Filsafat, h. 127.

${ }^{21}$ Al-Syatibi, al-muwafaqat, Juz 2 h.9.

${ }^{22}$ Ibid., h. 6-7.
} 
dimaksudkan untuk mengantisipasi terjadinya benturan antara masalah yang lain dalam tingkat pertama, daruriyat, harus didahulukan dari pada kelompok tingkat kedua, hajiyat dan kelompok tingkat kedua hajiyat harus didahulukan dari pada kelompok tingkat ketiga, tahsiniyat. ${ }^{23}$ Adapun ketika tidak terjadi benturan, maka setiap masalah tersebut harus atau perlu mendapat perhatian.

Keadaan di atas terbatas pada yang berbeda tingkat. Adapun dalam kasus yang tingkatnya sama, seperti daruriyat dengan daruriyat, maka penyelesaiannya adalah:

1. Jika benturan itu terjadi dalam urutan yang berbeda dari kelima pokok tersebut, maka skala prioritas didasarkan pada urutan yang sudah baku, yaitu agama harus didahulukan dari pada jiwa, jiwa harus didahulukan dari pada akal, dan seterusnya.

2. Jika benturan itu terjadi dalam tingkat dan urutan yang sama, seperti sama-sama menjaga harta dalam peringkat daruriyat, maka harus dilakukan penelitian terhadapnya dari segi cakupan kemaslahatan itu sendiri atau faktorfaktor lain yang menguatkan salah satu kemaslahatan yang harus didahulukan.

Oleh karena itu, syari'at Islam diturunkan untuk kemaslahatan manusia di dunia dan di akhirat. Tujuan syari'at yang sudah diketahui dan menjadi perhatian para fuqaha dalam ijtihad mereka sejak masa awal Islam kemudian mendapat penegasan dengan dirumuskannya teori maqashid al-syari'ah. Teori itu pada intinya menegaskan bahwa syari'at Islam bertujuan untuk; (1) memelihara, pada tingkat daruriyat, eksistensinya agama, jiwa, akal, keturunan dan harta, (2) menghindarkan, pada tingkat hajiyat, kesulitan dan kesempitan yang dapat dialami mukallaf dalam memelihara kelima unsur pokok tersebut dan (3) pada tingkat tahsiniyat, menjaga, kepantasan dan menjauhi ketidakpantasan dalam rangka memelihara kelima unsur pokok tersebut diatas.

${ }^{23}$ Fathurrahman Djamil, Filsafat, h. 132. 


\section{PENUTUP}

\section{A. Simpulan}

Berdasarkan dari pembahasan di atas, maka ditarik simpulan sebagai berikut:

1. Teori maqashid al-syari'ah, menjadi tumpuan utamanya adalah kemaslahatan dunia dan akhirat. Hal itu baru direalisasikan apabila kelima unsur pokok bsa diwujudkan dan dipelihara. Kelima unsur pokok (al-kuliyyat al-khams) tersebut, adalah memelihara agama, jiwa, akal, keturunan dan harta. Dan lima unsur itu, selanjutnya dibedakan de dalam tiga peringkat kebutuhan, berturut-turut dar-riyyat, hajiyyat dan tahsiniyyat.

2. Maqashid al-syari'ah pada dasarnya dapat dibagi menjadi dua macam, yaitu; dari sisi tujuan syar'I, dan kedua adalah sisi tujuan mukallaf.

\section{B. Saran}

Maqashid al-Syari'ah mempunyai peranan penting dalam melakukan istinbat hukum. Oleh karena itu, diperlukan kajian dan pendalaman terhadap teori maqashid al-syari'ah sebagai upaya untuk memahami filsafat hukum Islam. Selain itu, kajian dan pendalaman terhadap konsep maqashid al-syari'ah, perlu dikembangkan pada lembaga pendidikan Islam pada umumnya, dan pada fakulas Syariah pada khususnya. 


\section{DAFTAR PUSTAKA}

Bakri, Asfafri Jaya, Konsep Maqashid Syari'ah Menurut alSyatibi, Jakarta: Rajawali Press, 1999.

Djamil, Fathurrahman, Filsafat Hukum Islam, Jakarta: Logos, 1998.

Khallaf, Abd. Al-Wahab, Ilmu Ushul Fiqh, Kuwait: Dar al Qolam, 1983.

Manzur, Ibn, Lisan al-Arab, Jilid VII, Beirut; Dar al-Fikr, t.th.

Mas'ud, Muhammad Khalid, Islamic Legal Phylosophy, Islamabad: Islamic Research Imstitute, 1997.

al-Qaththan, Manna', al-Tasyri' wa al-Fiqh fi al-Islam, (Beirut: Muassasah al-Risalah, t.th.

al-Syatibi, Muhammad Ab-Ishak, al-Muwafaqat fi Ushul alSyari'ah, Jilid II, Kairo: Mustafa Muhammad, t.th.

Wehr, Hans, A Dictionary of Modern Written Arabic, London: George Allen and Unwin Ltd, 1997. 